\title{
JPEB
}

Jurnal Penelitian Ekonomi dan Bisnis, 4 (2), 2019, Hal: 106-119

http://www.jpeb.dinus.ac.id

\section{PENGARUH INSENTIF DAN PEMANTAUAN : DAMPAK TERHADAP ORIENTASI KEUANGAN DAN NON-KEUANGAN DALAM PENGANGGARAN MODAL}

\author{
Savika Wulandari ${ }^{1}$ dan Grace Tianna Solovida ${ }^{2 *}$ \\ ${ }^{1,2}$,Program Studi Akuntansi, STIE Bank BPD Jateng \\ Jalan Soekarno Hatta No 88 Semarang, Indonesia \\ ${ }^{*}$ Corresponding Email: tianna3186@gmail.com
}

Diterima: Mei 2019; Direvisi: Agustus 2019; Dipublikasikan: September 2019

\begin{abstract}
This research aimed to investigate the influence of incentive and monitoring provided to the decision maker that impacted on finance and non-finance orientation in budget planning. The independent variable in this study was incentive and monitoring in budget planning focusing on the project recommendation selection. While the dependent variable was finance and non-finance orientation in budget planning. The research employed an experimental method using descriptive statistics analysis applying a case study approach. The analysis involved multinomial logistics regression using a statistics computer application. The result of this study indicated that the decision maker did not provide significant evidence that s/he made a high emphasis on the finance and nonfinance orientation without incentive and monitoring. However, the decision maker receiving private incentive emphasized highly on cash inflows and a low emphasis on cash outflows, or vice versa.
\end{abstract}

Keywords: Budget Planning; Project Selection; Finance Orientation; Non-Finance Orientation; Private Incentive; Monitoring

\section{ABSTRAK}

Penelitian ini bertujuan untuk mengetahui pengaruh adanya insentif dan pemantauan yang diberikan kepada pengambil keputusan akan berdampak padaorientasi keuangan dan non keuangan dalam penganggaran modal.Variabel independen dalam penelitian ini adalahinsentif dan pemantauan dalam penganggaran modal yang difokuskan pada pemilihan rekomendasi proyek, sedangkan variabel dependen penelitian ini adalah orientasi keuangan dan orientasi non keuangan dalam penganggaran modal. Metode penelitian ini adalah dengan menggunakan metode eksperimen melalui pendekatan studi kasus dan analisis statistik deskriptif. Metode analisis dalam penelitian dengan menggunakan regresi logistik multinomial.Hasil dari penelitian ini dengan tidak adanya insentif dan pemantauan adalah pengambil keputusan tidak memberikan bukti yang signifikan bahwa pengambil keputusan memberikan penekanan yang lebih tinggi pada orientasi keuangan daripada orientasi non keuangan. Namun ketika pengambil keputusan menerima insentif pribadi, pengambil keputusan memberikan penekanan yang lebih tinggi pada arus kas masuk dan memberikan penekanan yang lebih rendah pada arus kas keluar. Atau ketika pengambil keputusan menerima insentif pribadi dan pemantauan, pengambil keputusan memberikan penekanan yang lebih rendah pada arus kas masuk dan memberikan penekanan yang lebih tinggi pada arus kas keluar.

Kata Kunci: Pengambilan Keputusan Penganggaran Modal; Pemilihan Proyek; Rekomendasi Proyek Penganggaran Modal; Orientasi Keuangan; Orientasi Non Keuangan; Insentif Pribadi; Pemantauan; Percobaan Pilihan Diskrit 


\section{PENDAHULUAN}

Sistem pengendalian manajemen memiliki peranan penting bagi keberlangsungan perusahaan yakni sebagai pengukur kinerja perusahaan, artinya bahwa kinerja perusahan dapat diukur melalui sistem pengendalian manajemen yang diterapkan, sehingga dalam hal ini perusahaan akan mudah mengetahui apakah tingkat kinerja perusahaan baik atau buruk. Setelah pengukuran kinerja dilakukan maka manajemen akan melakukan evaluasi sebab dan akibat keberhasilan atau kegagalan yang dialami oleh perusahaan. Penelitian ini akan membahas pula mengenai insentif pribadi dalam sistem pengendalian manajemen yang mungkin akan berdampak bagi pengambil keputusan dalam proses penganggaran modal.

Penganggaran adalah proses kegiatan yang menghasilkan anggaran sebagai hasil kerja, serta proses kegiatan yang berkaitan dengan pelaksanaan fungsi anggaran, yaitu fungsi pedoman kerja, alat pengoordinasian kerja, dan alat pengawasan kerja (Kariuki,2010). Penganggaran memiliki dua klasifikasi yaitu penganggaran modal dan penganggaran operasional. Dalam penelitian ini difokuskan pada penganggaran modal. Penganggaran modal sering kali disebut dengan pemrograman yang melibatkan identifikasi program dari tindakan khusus seperti proyek yang diimplementasikan atau investasi yang dilakukan untuk beberapa tahun ke depan dan spesifikasi dari masing-masing sumber daya yang digunakan (Merchant dan Stede, 2014). Penganggaran modal dibuat sesuai dengan tujuan perusahaan, sehingga proses penganggaran modal akan melibatkan orang-orang yang berpengalaman dalam hal analisis investasi perusahaan. Penganggaran modal merupakan penganggaran untuk jangka pajang sehingga dalam perencanaannya pun harus lebih terperinci jika dibandingkan dengan penganggaran jangka pendek (penganggaran operasional). Suatu perusahaan dapat dikatakan sukses atau berhasil dalam pengelolaan keuangannya apabila penganggaran modal secara efektif dapat dilakukan sesuai dengan tujuan perusahaan. Dalam hal ini salah satu peran yang sangat penting adalah peran pengambil keputusan.

Proses penganggaran modal biasanya dimulai dengan diskusi antara seluruh manajer dan bawahannya mengenai program yang dibutuhkan dalam waktu yang akan datang. Sebagai bagian dari proses ini, manajer harus meninjau kembali program yang sedang berjalan untuk menilai apakah mereka memenuhi tujuan yang diharapkan perusahaan dan apakah mereka seharusnya memodifikasi atau menghentikannya (Merchant dan Stede, 2014). Jika pengambil keputusan dalam penganggaran modal harus cermat memahami proses pengambilan keputusan maka diharapkan pengambil keputusan mampu menunjang kesuksesan perusahaan. Proses pengambilan keputusan adalah salah satu proses pemikiran manusia yang paling kompleks, karena dalam proses pengambilan keputusan akan mempertimbangkan berbagai faktor dan tindakan yang melibatkan campur tangan berbagai pihak yang berperan didalamnya dengan hasil yang berbeda-beda (Lubis, 2013).

Fenomena pengambilan keputusan pada penganggaran modal masih banyak terjadi di Indonesia. Penganggaran modal sangat mempengaruhi keputusan investasi mengenai proyek ke depan. Keputusan investasi merupakan salah satu rasio profitabilitas yang menunjukkan kemampuan perusahaan dalam menghasilkan laba. Keputusan investasi menunjukkan kembalian atau laba perusahaan yang dihasilkan dari modal perusahaan yang digunakan untuk menjalankan perusahaan. Semakin besar rasio ini maka profitabilitas perusahaan akan semakin baik. Modal ini juga merupakan unsur utama penting yang mempengaruhi pencapaian nilai atas target laba yang telah direncanakan. Oleh karena itu, dalam hal ini perusahaan berusaha mengeluarkan modal seminimal mungkin. Ada beberapa faktor yang berpengaruh terhadap tingkat keputusan investasi perusahaan antara lain; stabilitas penjualan, struktur aktiva, struktur pendanaan, profitabilitas, pajak,p pengendalian, sikap manajemen, sikap pemberi pinjaman dan lembaga penilai peringkat, kondisi pasar, kondisi internal perusahaan, fleksibilitas keuangan (Triastuti, Ningsih, \& Diba, 2018).

Pengambil keputusan akan melihat orientasi keuangan dan non-keuangan dalam 
penganggaran modal untuk proyek ke depan, namun tidak hanya hal tersebut, pengendalian sikap manajemen juga sangat mempengaruhi pengambil keputusan. Dengan demikian, pengambil keputusan yang menerima insentif pribadi mampu untuk mengamankan proyek ke depan, persetujuan mereka diharapkan untuk menyelaraskan perilaku ini dengan membuat keputusan terbaik dari motivasi ekstrinsik (Wagner III dan Gooding, 1997).

Literatur keuangan perusahaan membagi proses penganggaran modal menjadi empat tahap yaitu identifikasi proyek, pengembangan proyek, pemilihan proyek, dan pengendalian proyek (Burns dan Walker, 2009). Menurut Frezatti dkk, 2013 menjelaskan "Keputusan investasi jangka panjang mempengaruhi dan dipengaruhi oleh masalah agensi karena agen dan principal yang berbeda presepsi dalam faktor risiko, hubungan agen dan principal (khususnya mengenai metode penilaian kinerja agen oleh principal), dan penilaian dan mekanisme dukungan proses keputusan masing-masing pihak".

Beberapa penelitian melakukan tahap seleksi mengenai penerapan orientasi keuangan dan non-keuangan dalam penganggaran modal (Burns dan Walker, 2009), salah satu penelitian survai yang dilakukan berfokus pada penerapan teknik seleksi yang berorientasi keuangan (Haka, 2007). Namun, sementara keputusan investasi mungkin keputusan keuangan, ada penelitian yang semakin berkembang menyatakan bahwa keputusan investasi juga sering didasarkan pada orientasi non-keuangan. Pada penelitian ini, orientasi non-keuangan meliputi faktor-faktor strategis (misalnya,tingkat fit pada proyek penganggaran modal dan bisnis strategi), faktor-faktor politik/risiko (misalnya, jalur investasi, catatan sponsor), dan faktor intuitif/kinerja (misalnya, efek pada moral personil dalam suatu organisasi) (Butler, Davis, Pike, dan Sharp, 1993; Guilding, 2003).

Proses penganggaran modal selain mempertimbangkan orientasi keuangan dan nonkeuangan, pengambil keputusan akan dipengaruhi oleh adanya insentif dan pemantauan dalam proses penganggaran. Tingkat penekananan arus kas masuk dan arus kas keluar (orientasi keuangan) mungkin akan berbeda jika pengambil keputusan hanya mendapatkan insentif pribadi dibandingkan ketika pengambil keputusan menerima insentif pribadi dan pemantauan. Insentif pribadi memiliki tujuan untuk mendorong pengambil keputusan untuk melakukan usaha ekstra dalam melakukan tugas dengan baik, kadang kala disebut tujuan yang mampu menimbulkan usaha (Merchant dan Stade, 2014), namun mengingat pentingnya faktor keuangan yakni perubahan arus kas yang terjadi dalam proses penganggaran modal (Bennouna, Meredith, \& Marchant, 2010) dan preferensi pengambil keputusan (Chen, 2008; Turner dan Guilding, 2012), pengambil keputusan hanya melihat posisi terbaik sesuai tujuan pribadi mereka untuk memberikan penekanan yang lebih tinggi pada proyeksi arus kas masuk dan memberikan penekanan yang lebih rendah pada arus kas yang diproyeksikan sehingga dapat meningkatkan kemungkinan penerimaan proyek (Canteralli, Flyvbjerg, Molin, dan van Wee, 2008).

Berbeda ketika perusahaan memberikan insentif pribadi beserta pemantauan melalui post audit, pengambil keputusan cenderung menghindari membuat pilihan untuk merekomendasikan proyek investasi atau tidak (Luce, 1998). Pengambil keputusan akan dihadapkan pada kondisi moral yang ada pada diri masing-masing individu atau ada aspek psikologi yang berperan didalamnya. Ada dua kondisi yang sering dibahas pada metode pengambilan keputusan mungkin untuk membatasi perilaku melayani diri sendiri serta untuk menyelaraskan kepentingan manajer dan pemilik perusahaan (Jensen dan Meckling, 1976). Penelitian ini membahas mengenai perubahan peran yang mungkin dapat terjadi pada pengambil keputusan dalam proses penganggaran modal untuk proyek ke depan apabila insentif dan pemantauan diberikan. Pasca audit pada dasarnya dirancang untuk mengevaluasi efisiensi manajer dan menilai akurasi asumsi dasar serta memperkirakan keputusan awal manajer yang dibuat sebelum menerima proyek yang dapat dilanjutkan (Chenhall dan Morris, 1993). Namun disisi lain pasca audit dapat memiliki efek merusak dimana agen bisa menjadi 
lebih konservatif atau bahkan menghindar dari proyek ketika mengajukan proyek penganggaran modal (Koch, et al., 2009). Adanya dua kondisi mengenai sikap manajer dalam melayani kepentingan diri sendiri akan berdampak pada manajemen umum perusahaan, jika manajer tingkat atas yakin bahwa gaji pengambil keputusan akan sesuai dengan pelayanan yang diberikan oleh pengambil keputusan penganggaran modal maka akan mudah mencapai kesejahteraan perusahaan dan pemantauan akan diberikan secara minimal karena akan terbentuk timbal balik kepercayaan yang menggantikan kontrol formal seperti pemantauan ketat atau kompensasi insentif (Davis dkk, 1997), sehingga hal tersebut penting untuk diteliti.

Berdasarkan uraian diatas maka rumusan masalah yang akan ditelaah pada penelitian ini antara lain sebagai berikut:

1. Bagaimana tingkat relatif penekanan pada orientasi keuangan dan non-keuangan dalam proses penganggaran modal?

2. Apakah dampak adanya insentif pribadi mampu untuk melanjutkan rekomendasi proyek investasi?

3. Apakah dampak adanya insentif pribadi dan pemantauan mampu untuk melanjutkan rekomendasi proyek investasi?

Temuan penelitian ini difokuskan pada tahap pemilihan proyek, yang memiliki tujuan yaitu:

1. Memberikan bukti empiris bahwa pengambil keputusan akan memberikan tingkat penekanan yang berbeda pada orientasi keuangan dan non-keuangan dalam praktik penganggaran modal.

2. Memberikan bukti empiris mengenai adanya insentif pribadi yang diberikan kepada pengambil keputusan akan mempengaruhi tingkat penekanan terhadap orientasi keuangan yaitu arus kas masuk dan arus kas keluar serta orientasi non-keuangan dalam penganggaran modal.

3. Memberikan bukti empiris mengenai adanya insentif pribadi bersama pemantauan melalui post audit yang diberikan kepada pengambil keputusan akanakan mempengaruhi tingkat penekanan terhadap orientasi keuangan yaitu arus kas masuk dan arus kas keluar serta orientasi non-keuangan dalam penganggaran modal.

\section{TINJAUANPUSTAKA}

\section{Teori Agensi}

Penjelasan mengenai penganggaran modal dimulai dari pendekatan teori agensi. Teori agensi dapat didefinisikan sebagai konsep yang menjelaskan mengenai kontrak antara satu orang atau lebih bertindak sebagaipemilik menunjuk manajer sebagai agen untuk melakukan jasa guna kepentingan pemilik termasuk mendelegasikan kekuasaan dalam pengambilan keputusan (Jensen dan Mackling, 1976). Penganggaran modal merupakan penganggaran untuk jangka panjang, yang sangat berdampak pada kelangsungan hidup perusahaan. Manajer yang ditunjuk sebagai pengambil keputusan diharapkan dapat melakukan pekerjaan dengan baik, namun salah satu penyebab adanya konflik teori agensi ini adalah ketika pengambil keputusan tidak bekerja sesuai tujuan perusahaan tetapi bekerja sesuai tujuan pribadi (Hiebl, 2015). Konflik pada teori agensi ini tentu akan berdampak secara langsung pada proses penganggaran modal.

\section{Teori Kontinjensi}

Para peneliti telah menerapkan pendekatan kontinjensi guna menganalisis dan mendesain sistem pengendalian, khususnya di bidang sistem akuntansi manajemen. Beberapa peneliti dalam bidang akuntansi manajemen melakukan pengujian untuk melihat hubungan variabel kontekstual seperti ketidakpastian lingkungan, ketidakpastian tugas, struktur dan budaya organisasi, ketidakpastian strategi dengan desain sistem akuntansi manajemen (Otley, 1980). 
Teori kontinjensi menyatakan bahwa tidak ada rancangan dan sistem pengendalian tertentu hanya efektif untuk kondisi atau organisasi tertentu (Otley, 1999). Dalam pendekatan teori kontinjensi ini maka memungkinkan adanya variabel-variabel lain yang dapat mempengaruhi proses pengambilan keputusan dalam penganggaran modal. Berdasarkan teori kontinjensi maka akan terdapat suatu kondisi yang mungkin berhubungan dengan kondisi lain yang mana saling mempengaruhi.

\section{Penganggaran Modal}

Quirin (1967), mengemukakan bahwa penganggaran modal adalah proses yang ditetapkan untuk berinvestasi sumber dana lebih efisien dan efektif untuk menghasilkan arus dana masa depan dalam jangka panjang. Penelitian lain yang berbeda mendefinisikan penganggaran modal dengan cara yang berbeda. Dengan demikian Sagelod (1997), mendefinisikan bahwa "penganggaran modal sebagai prosedur, rutinitas, metode dan teknik yang digunakan untuk mengidentifikasi peluang investasi, untuk mengembangkan ide-ide awal dalam proposal investasi tertentu, untuk mengevaluasi dan memilih proyek dan untuk mengontrol proyek investasi guna menilai perkiraan akurasi ".

Praktik penganggaran modal dimaksudkan untuk menganalisis beberapa alternatif investasi yang tersedia, kemudian menetapkan atau memilih yang paling menguntungkan. Ketidaktepatan dalam menetapkan pilihan investasi menimbulkan kerugian riil ataupun kerugian karena kehilangan kesempatan untuk memperoleh manfaat yang lebih menguntungkan (opportunity cost) yang sebenarnya dapat diwujudkan. Analisis investasi akan menyeleksi kesempatan yang ada, sehingga dapat dipilih yang memberikan manfaat terbesar dari setiap rupiah dana yang diinvestasikan (Riyanto, 2015).

\section{Insentif Pribadi}

Insentif adalah semua pendapatan berbentuk uang, barang langsung atau tidak langsung yang diterima oleh pegawai sebagai imbalan atas jasa yang diberikan oleh organisasi atau perusahaan (Hasibuan, 2001). Insentif adalah perangsang yang ditawarkan kepada karyawan untuk melaksanakan pekerjaan yang sesuai atau lebih tinggi dari standar-standar yang telah ditetapkan (Handoko, 2002). Insentif adalah kompensasi yang mengaitkan gaji dengan produktivitas. Dari berbagai pengertian diatas dapat disimpulkan bahwa insentif merupakan penghargaan dalam bentuk keuangan maupun non-keuangan yang diberikan kepada mereka yang dapat bekerja melampaui standar serta target yang telah disepakati (Panggabean, 2002).

Penting untuk mengenali bahwa ada kecenderungan bawaan manusia untuk menganggap bahwa imbalan ekstrinsik berperan membimbing dalam membentuk perilaku karyawan (Kadous, Koonce, dan Towry, 2005). Seperti fenomena yang sedang terjadi saat ini di Indonesia mengenai pemberian insentif dan peraturan pemerintah yang mungkin akan membawa dampak baik maupun dampak buruk bagi para pengambil keputusan. Biasanya pengambil keputusan membuat proposal penganggaran modal yang menerima insentif pribadi agar mampu mengamankan proyek ke depan, persetujuan pemilik perusahaan terhadap penerimaan proyek diharapkan untuk menafsirkan perilaku ini dengan menggunakan ketrampilannya untuk memahami perilaku maupun rekomendasi proyek dari motivasi ekstrinsik yang diberikan (Wagner III \& Gooding, 1997).

\section{Pemantauan Melalui Post Audit}

Pasca audit dirancang untuk mengevaluasi efisiensi manajer dan menilai asumsi akurasi dasar serta memperkirakan efisiensi awal pengajuan proposal penganggaran modal sebelum menerima proyek untuk dapat dilanjutkan (Chenhall dan Morris, 1993). Jika dilihat dari aspek psikologi, ketika pemantauan dikombinasikan bersama dengan insentif pribadi diharapkan pembuat keputusan mungkin akan lebih hati-hati dan menjadi sulit untuk membuat pilihan 
apakah akan merekomendasikan proyek atau tidak merekomendasikan proyek (Luce, 1998). Pengambil keputusan mungkin menganggap lebih baik untuk memiliki hasil yang buruk sebagai akibat dari kelambanan (yaitu, dengan tidak merekomendasikan proyek) daripada membuat kegagalan sebagai akibat dari tindakan (yaitu, dengan merekomendasikan proyek) (Zeelenberg, Inman, dan Pieters, 2001).

\section{Orientasi Keuangan dan Non-keuangan dalam Penganggaran Modal}

Proses penganggaran modal cenderung membutuhkan orientasi keuangan sebagai pengaruh yang lebih besar daripada orientasi non-keuangan, agar dalam pembuatan proposal investasi proyek dapat dilanjutkan (Turner dan guilding, 2012). Faktor selanjutnya adalah pengamatan bahwa pengguna umumnya lebih memprioritaskan informasi kuantitatif daripada informasi kualitatif (Porter, 1996). Hal tersebut menunjukan bahwa ukuran angka dianggap lebih meyakinkan dalam persetujuan penerimaan proyek untuk dapat dilanjutkan.

Meskipun informasi non-keuangan sering dianggap kurang penting di penganggaran modal (Chen, 2008; Turner dan guilding, 2012), namun informasi non-keuangan juga sering digunakan sampai batas tertentu untuk membantu dalam penganggaran modal pengambilan keputusan (Moyer, McGuingan, dan Kretlow, 2001).Proyek penganggaran modal dikatakan sukses tidak harus dibenarkan dengan alasan murni keuangan (Carr, et al., 1994). Penelitian ini akan menelaah pengaruh tingkat penekanan orientasi keuangan dan non keuangan dalam proses penganggaran modal.

\section{Pengembangan Hipotesis}

\section{Penekanan Orientasi Keuangan dan Non-keuangan dalam Penganggaran Modal.}

Dalam penelitian berbasis survei penerapan metode DCF (orientasi keuangan) lebih banyak digunakan daripada metode non-DCF seperti Payback Period, karena dianggap dalam akuntansi untuk tingkat keberhasilan suatu proyek akan lebih tinggi (Haka, 2007). Namun dalam perkembangan penelitian mengenai orientasi non-keuangan akan lebih mempengaruhi pengambilan keputusan dalam penganggaran modal masih relatif terbatas. Penelitian berbasis survei cross-sectional oleh Chen (2008) yang menunjukkan hasil bahwa CFO dari perusahaan manufaktur di AS sebagai responden lebih banyak menggunakan teknik DCF (orientasi keuangan) lebih penting dibandingkan dengan faktor-faktor non-keuangan. Sehingga didukung penelitian berbasis survei yang dilakukan oleh Turner dan Guilding (2012) dengan menggunakan skala likert menunjukkan bahwa sebagian besar orientasi keuangan memiliki pengaruh yang lebih tinggi daripada orientasi non-keuangan terhadap usulan investasi agar dapat dilanjutkan.

Pengambil keputusan diharapkan memberi penekanan lebih tinggi pada orientasi keuangan daripada orientasi non-keuangan dalam penganggaran modal. Hiposesis 1 secara konsisten berbunyi :

H1: Pengambil keputusan memberikan penekanan yang lebih tinggi pada orientasi keuangan daripada orientasi non-keuangan dalam penganggaran modal.

\section{Dampak Insentif Pribadi untuk Proyek Dapat Dilanjutkan.}

Adanya insentif pribadi akan menimbulkan motivasi ekstrinsik pada pengambil keputusan untuk rekomendasi proyek kedepan (Cheng dan Mahama, 2011), dengan demikian pengambil keputusan yang menerima insentif pribadi diharapkan mampu untuk mengamankan proyek yang akan dilanjutkan oleh perusahaan (Wagner III \& Gooding, 1997).

Pengambil keputusan hanya melihat posisi terbaik sesuai tujuan pribadi mereka untuk memberikan penekanan yang lebih tinggi atas proyeksi arus kas masuk dan memberikan penekanan yang lebih rendah atas arus kas yang diproyeksikan sehingga dapat meningkatkan kemungkinan penerimaan proyek (Cantarelli, Flyvbjerg, Molin, dan van Wee, 2008). 
Sedangkan pemilik perusahaan mengharapkan pemberian insentif mampu memberikan nilai bagi manajemen jangka panjang (Hiebl, 2015). Berdasarkan uraian tersebut, maka secara konsisten berbunyi hipotesis $2 \mathrm{a}$ dan hipotesis $2 \mathrm{~b}$ sebagai berikut:

H2a: Pengambil keputusan yang menerima insentif pribadi untuk rekomendasi proyek yang mungkin dapat dilanjutkan akan memberikan penekanan yang lebih tinggi atas arus kas masuk dalam penganggaran modal.

$\mathrm{H} 2 \mathrm{~b}$ : Pengambil keputusan yang menerima insentif pribadi untuk rekomendasi proyek yang mungkin akan dilanjutkan akan memberikan penekanan yang lebih rendah atas arus kas keluar dalam penganggaran modal.

Dengan adanya hipotesis $2 \mathrm{a}$ dan $2 \mathrm{~b}$ maka munculah hipotesis $2 \mathrm{c}$ yaitu proyek investasi penganggaran modal dikatakan sukses tidak perlu dibenarkan karena alasan murni keuangan (Carr dkk, 1994). Pengambil keputusan diharapkan akan melihat kepentingan terbaik mereka yaitu memberikan penekanan yang lebih tinggi pada orientasi non-keuangan sehingga dapat meningkatkan kemungkinan proyek investasi dapat dilanjutkan (Khalil \& O 'sullivan, 2017). Sehingga dalam hal ini akan terlihat secara jelas pengaruh diberikannya insentif pribadi akan berdampak pada orientasi non-keuangan perusahaan dalam keputusan investasi. Berikut hipotesis $2 \mathrm{c}$ dengan konsisten berbunyi sebagai berikut:

H2c: Pengambil keputusan yang menerima insentif pribadi untuk rekomendasi proyek yang mungkin akan dilanjutkan akan memberikan penekanan yang lebih tinggi pada orientasi non-keuangan dalam penganggaran modal.

\section{Dampak Insentif Pribadi dan Pemantauan Untuk Proyek Dapat Dilanjutkan.}

Adanya insentif pribadi mampu memberikan motivasi ekstrinsik, namun ketika diberikan secara bersama dengan pemantauan melalui post audit akan mempengaruhi pengambil keputusan dalam praktik penganggaran modal. Tujuan pasca audit sebenarnya untuk mendorong peramalan yang lebih baik (rekomendasi proyek), karena dengan adanya pasca audit pengambil keputusan merasa kinerjanya akan ditinjau (Farragher, 1990). Dalam keadaan tersebut maka pengambil keputusan akan memainkan orientasi keuangan dan non orientasi keuangan yang berbanding terbalik dengan hipotesis sebelumnya.

Pembuat keputusan diharapkan untuk memberikan penekanan yang lebih rendah pada arus kas masuk dan tingkat penekanan yang lebih tinggi pada arus kas keluar sehingga membuat rekomendasi proyek membawa risiko kegagalan yang lebih rendah (Khalil \& O 'sullivan, 2017). Tentunya dalam uraian diatas memperlihatkan bahwa adanya pemantauan post auditakan mengubah peran pengambil keputusan dalam praktik penganggaran modal dimana pengambil keputusan akan lebih hati-hati dalam melakukan sebuah tindakan karena mereka mengetahui bahwa pekerjaannya akan diteliti lebih cermat oleh pihak audit. Sehingga memunculkan hipotesis $3 \mathrm{a}$ dan $3 \mathrm{~b}$ yang secara konsisten berbunyi sebagai berikut:

H3a: Pengambil keputusan yang menerima insentif pribadi dan yang dipantau melalui post audit akan membuat penekanan yang lebih rendah pada arus kas masuk dalam penganggaran modal.

$\mathrm{H} 3 \mathrm{~b}$ : Pengambil keputusan yang menerima insentif dan yang dipantau melalui post audit akan memberikan penekanan yang lebih tinggi pada arus kas keluar dalam penganggaran modal.

Pengambil keputusan diharapkan menjadi kurang risk averse dengan menekankan lebih tinggi pada informasi non-keuangan sehingga dapat meningkatkan kemungkinan penerimaan proyek (Khalil \& O 'Sullivan, 2017). Sehingga akan lebih mempertimbangkan apakah akan melanjutkan rekomendasi proyek atau tidak dengan lebih melihat pada orientasi non keuangan. Berikut hipotesis 3c secara konsisten berbunyi sebagai berikut: 
H3c: Pengambil keputusan yang menerima insentif pribadi dan pemantauan melalui post audit akan memberikan penekanan yang lebih tinggi pada orientasi non-keuangan dalam penganggaran modal.

\section{Model Penelitian}

Model penelitian ini menggunakan model penelitian yaitu model bersyarat artinya model dibuat berdasarkan jalur yang sesuai dengan kondisi yang akan diteliti dan sesuai dengan hipotesis. Berikut gambar model penelitian ini :

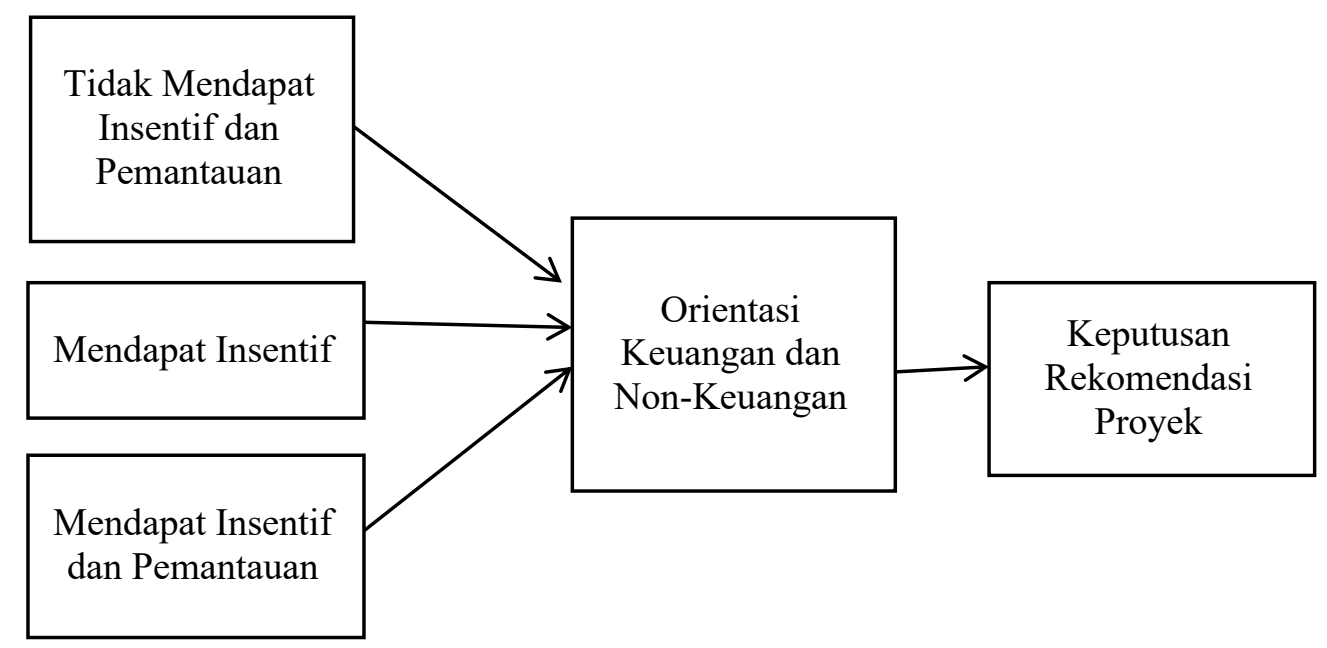

\section{Gambar 1. Model Penelitian}

\section{METODEPENELITIAN}

\section{Definisi Operasional}

Definisi operasional mempunyai interpretasi tunggal, oleh karena itu tabel dibawah ini merupakan penjelasan secara spesifik setiap variabelnya :

Tabel 1.Definisi Operasional

$\begin{array}{llc}\text { Variabel Penelitian } & \begin{array}{l}\text { Indikator } \\ \text { Penelitian }\end{array} & \text { Skala } \\ & \text { Penelitian }\end{array}$

\begin{tabular}{llc}
\hline Penganggaran Modal $(\mathrm{Z})$ & Pemilihan proyek. & Likert \\
\hline Insentif Pribadi $\left(\mathrm{X}_{1}\right)$ & Kepentingan pribadi & Likert \\
& Motivasi ekstrinsik & \\
& Perilaku karyawan & \\
\hline Pemantauan $\left(\mathrm{X}_{2}\right)$ & Mekanisme kontrol keuangan & Likert \\
& Evaluasi kinerja operasi proyek & \\
& Siklus hidup investasi. & \\
\hline Orientasi keuangan $\left(\mathrm{Y}_{1}\right)$ & Arus kas masuk & Likert \\
& Arus kas keluar & \\
\hline Orientasi Non-Keuangan $\left(\mathrm{Y}_{2}\right)$ & Faktor strategi & Skala \\
& Faktor risiko & Penelitian \\
& Faktor kinerja (prestasi) & \\
\hline
\end{tabular}

\section{Populasi dan Sampel}

Populasi yang digunakan dalam penelitian ini adalah populasi dari beberapa universitas atau perguruan tinggi yang ada di Semarang. Penelitian ini dilakukan pada 5 Universitas atau Perguruan Tinggi Swasta besar yang ada di Semarang, sehingga akan menghasilkan populasi 
yang besar karena penggabungan dari berberapa populasi, maka akan mempengaruhi dalam teknik pengambilan sampel. Tujuan dalam pengambilan sampel dikarenakan adanya populasi yang terlalu besar dan luas sehingga tidak memungkinkan melakukan pengambilan data dari keseluruhan populasi.

Sampel dalam penelitian ini menggunakan non-probability sampling/non random sample. Penelitian ini memilih metode purposive sampling yaitu metode yang dilakukan untuk pengambilan sampel dengan menentukan kriteria yang telah di tentukan oleh responden. Kriteria sampel penelitian ini adalah mahasiswa akuntansi yang telah memiliki pengetahuan mengenai penganggaran modal, mahasiswa akuntansi yang terdaftar telah menempuh pendidikan minimal tiga tahun di universitas yang ada di Semarang. Pilihan mahasiswa akuntansi sebagai pengganti akuntan profesional karena ada beberapa alasan kuat, yaitu :

1. Pertama, Waldron dan Faisher (2017) menyoroti kesesuaian mahasiswa akuntansi sebagai pengganti akuntan profesional, terutama dimana tugas melibatkan keputusan investasi.

2. Kedua, Swain dan Haka (2000) mahasiswa akuntansi sebagai pengganti akuntan profesional akan memperlihatkan ada perbedaan yang jelas dalam keputusan penganggaran modal dari penganggaran modal berpengalaman dan tidak berpengalaman.

3. Ketiga, ada banyak contoh studi dalam literatur penganggaran modal yang telah disediakan argumen yang kuat dalam mendukung penggunaan mahasiswa akuntansi sebagai pengganti akuntan profesional (Brown dan Solomon, 1993; Cheng dan Mahama, 2011; Cheng dkk, 2003; Kerler III dkk, 2014).

\section{Metode Pengumpulan Data}

Data diperoleh dengan kuesioner yang dibagikan kepada mahasiswa akuntasi terpilih. Instrumen penelitian berisi skenario kasus yang mengadopsi pendekatan yang diambil di Carr dan Tomkins (1998) dengan berfokus pada satu industri. Industri tertentu yang dipilih adalah industri hotel, yang dicirikan memiliki intensitas modal yang tinggi (ISHC 2015). Guilding (2003) melihat bahwa penganggaran modal diberikan lebih kompleks di hotel yang beroperasi dengan kontrak manajemen. Manipulasi insentif pribadi dan pemantauan yang tertanam dalam skenario.

\section{Metode Analisis Data}

Pada tahap analisis data tentunya penelitian ini harus memiliki metode yang sesuai dengan konteks penelitian guna menyelesaikan permasalahan yang diteliti.

\section{Analisis Statistik Deskriptif}

Analisis statistik deskriptif dengan metode pendekatan studi kasus telah digunakan secara luas di beberapa bidang seperti ekonomi terapan dan psikologi, pemasaran, dan transportasi dan studi logistik (Hensher, Rose, \& Greene, 2005; Louviere, Hensher, \& Swait, 2000).Atribut telah dipilih untuk menjadi wakil dari jenis informasi yang biasanya pengambil keputusan mengevaluasi proyek penganggaran modal untuk rekomendasi proyek. Untuk tujuan ini Butler dkk (1993) membuat kategorisasi informasi keuangan dan informasi non-keuangan dalam penganggaran modal yang telah diadopsi dengan pendekatan secara umum lebih spesifik dari skenario kasus kontekstual. Penelitian ini berfokus pada satu industri yaitu industri perhotelan, untuk mempermudah penelitian maka dibuatlah kode untuk atribut sebagai berikut: dua faktor keuangan yaitu arus kas masuk (F1) dan arus kas keluar (F2), tiga faktor strategis yaitu proyek penganggaran modal cocok dengan strategi bisnis (S1), kondisi hotel pesaing merupakan informasi untuk perbaikan manajemen hotel (S2), dan peningkatan keseluruhan kinerja operasional hotel (S3), dua faktor risiko, dampak dari perubahan ekonomi pada proyek (perubahan yaitu, internal atau eksternal) (R1), dan dampak pada kondisi keuangan hotel jika proyek gagal (R2), dan dua faktor kinerja, Pengaruh proyek pada kualitas produk (P1), dan 
pengaruh proyek pada moral Staf hotel (P2).

Penelitian ini menggunakanalat analisis SPSS yaitu regresi logistik multinomial dengan variabel responnya bersifat kualitatif, (Hosmer dan Lemeshow, 1989). Penggunaan regresi logistik multinominal dikarenakan dalam penelitian ini variabel dependen memiliki kategori lebih dari dua.

\section{Menilai Model Fit}

Menilai model fit dilakukan dengan melakukan penaksiran parameter model, uji signifikan parameter dan uji kecocokan model.

\section{Interpretasi Parameter Regresi Logistik}

Cara yang dipakai untuk melakukan interpretasi parameter regresi logistik adalah dengan menggunakan rasio Odds(Hosmer dan Lemeshow, 1989).Odds adalah suatu perbandingan probabilitas kejadian sukses dengan kejadian yang tidak sukses dalam suatu kategori.

\section{HASIL DANPEMBAHASAN}

\section{Pengambil Keputusan Tidak Mendapat Insentif Dan Pemantauan (Kondisi 1)}

Kondisi pertama dalam penelitian ini mendukung pada hipotesis pertama (H1) yang berbunyi secara konsisten adalah pengambil keputusan memberikan penekanan yang lebih tinggi pada orientasi keuangan daripada orientasi non-keuangan dalam penganggaran modal. Pada kondisi 1 sesuai untuk menjawab hipotesis 1 karena di dalam kuesioner ada kasus yang diberikan kepada pengambil keputusan tidak tertanam skenario insentif dan pemantauan, artinya data yang diperoleh hanya mempertimbangkan orientasi keuangan dan non keuangan dalam penganggaran modal saja. Berdasarkan hasil respon responden dengan menggunakan statistik deskriptif pengambil keputusan memberikan jawabanuntuk F1 (arus kas masuk) sebagai orientasi keuangan cenderung memilih pada skala 2 yaitu 6 miliyar per tahun, sedangkan untuk S1 (faktor strategis 1) sebagai orientasi non keuangan cenderung memilih pada skala 2 yaitu fit proyek penganggaran modal dengan strategis bisnis baik.

Seperti penelitian berbasis survei cross-sectional oleh Chen (2008) yang menunjukkan hasil bahwa CFO dari perusahaan manufaktur di AS sebagai responden lebih banyak menggunakan teknik DCF (orientasi keuangan) lebih penting dibandingkan dengan faktorfaktor non-keuangan namun hal tersebut tidak didukung oleh data yang tidak signifikan hal ini sesuai dengan penelitian Khalil \& O 'Sullivan (2017) menunjukkan bahwa pengambil keputusan dalam praktik penganggaran modal tidak memberikan penekanan lebih tinggi pada orientasi keuangan daripada orientasi non-keuangan.

Mengenai faktor strategis 1 (S1) yang signifikan dan menunjukkan penekanan yang lebih rendah maka sesuai dengan penelitian terdahulu dari Chen (2008) serta Turner dan Guilding (2012) yang menunjukkan bahwa dalam penganggaran modal pengaruh faktor strategis memiliki penekanan yang lebih rendah dari pengaruh faktor keuangan.

\section{Pengambil Keputusan Mendapat Insentif (Kondisi 2)}

Kondisi kedua dalam penelitian ini mendukung pada hipotesis kedua, b, dan c (H2a, H2b, dan $\mathrm{H} 2 \mathrm{c}$ ). Pada kondisi 2 sesuai untuk menjawab hipotesis $2 \mathrm{a}, 2 \mathrm{~b}$, dan $2 \mathrm{c}$ karena di dalam kuesioner ada kasus yang diberikan kepada pengambil keputusan tertanam skenario insentif, artinya data yang diperoleh mempertimbangkan adanya insentif yang akan berdampak pada orientasi keuangan dan non keuangan dalam penganggaran modal. Berdasarkan hasil respon responden dengan menggunakan statistik deskriptif pengambil keputusan memberikan jawaban untuk F1 (arus kas masuk) sebagai orientasi keuangan cenderung memilih pada skala 2 yaitu 6 miliyar per tahun dan jawaban untuk F2 (arus kas keluar) sebagai orientasi keuangan 
cenderung memilih pada skala 3 yaitu 2 miliyar per tahun sedangkan untuk R2 (faktor risiko 2) sebagai orientasi non keuangan cenderung memilih pada skala 2 yaitu dampak kondisi keuangan hotel jika proyek gagal besar.

Pada kondisi kedua ini terlihat jelas bahwa ada pengaruh diberikannya insentif kepada pengambil keputusan. Pengambil keputusan memberikan bukti yang signifikan pada kas masuk (F1) dan kas keluar (F2). Pengambil keputusan memberikan penekanan yang lebih tinggi pada kas masuk dan memberikan penekanan yang lebih rendah pada kas keluar. Sesuai dengan penelitian oleh Khalil \& O'Sullivan (2017), pengambil keputusan hanya akan melihat posisi terbaik sesuai tujuan pribadi mereka (Cantarelli dkk, 2008). Namun tidak ada bukti yang signifikan apakah pengambil keputusan memberikan penekanan yang lebih tinggi pada faktor non-keuangan. Pada penelitian oleh Khalil \& O'Sullivan (2017) juga menjelaskan alasan lain bahwa mengukur hasil dari non-keuangan agak sulit dan subjektif karena pengambil keputusan menganggap hal tersebut akan menimbulkan kontrol yang rendah dalam penilaiannya.

\section{Pengambil Keputusan Mendapat Insentif dan Pemantauan}

Kondisi ketiga dalam penelitian ini mendukung pada hipotesis ketiga, b, dan c (H3a, $\mathrm{H} 3 \mathrm{~b}$, dan $\mathrm{H} 3 \mathrm{c}$ ).Pada kondisi 3 sesuai untuk menjawab hipotesis $3 \mathrm{a}, 3 \mathrm{~b}$, dan $3 \mathrm{c}$ karena di dalam kuesioner ada kasus yang diberikan kepada pengambil keputusan tertanam skenario insentif dan pemantauan, artinya data yang diperoleh mempertimbangkan adanya insentif dan pemantauan yang akan berdampak pada orientasi keuangan dan non keuangan dalam penganggaran modal. Berdasarkan hasil respon responden dengan menggunakan statistik deskriptif pengambil keputusan memberikan jawaban untuk F1 (arus kas masuk) sebagai orientasi keuangan cenderung memilih pada skala 2 yaitu 6 miliyar per tahun dan jawaban untuk F2 (arus kas keluar) sebagai orientasi keuangan cenderung memilih pada skala 2 yaitu 3 miliyar per tahun sedangkan untuk R2 (faktor risiko 2) sebagai orientasi non keuangan cenderung memilih pada skala 2 yaitu dampak kondisi keuangan hotel jika proyek gagal besar.

Pada kondisi ketiga ini terlihat jelas bahwa ada perubahan pengaruh psikologi pengambil keputusan ketika mereka diberikan insentif dan pemantauan. Pengambil keputusan memberikan bukti yang signifikan pada kas masuk (F1) dan kas keluar (F2). Sesuai dengan penelitian oleh Khalil \& O 'Sullivan (2017) menunjukkan bahwa adanya post auditdapat menyebabkan pengambil keputusan menjadi lebih konservatif atau bahkan menghindari proyek.Pengambil keputusan memberikan penekanan yang lebih rendah arus kas masuk dan penekan yang lebih tinggi arus kas keluar karena menganggap bahwa proyek penganggaran modal kurang menguntungkan, serta pengambil keputusan menganggap bahwa dengan memberikan penekanan yang lebih tinggi pada arus kas keluar akan meningkatkan pengendalian. Namun tidak ada bukti yang signifikan apakah pengambil keputusan memberikan penekanan yang lebih tinggi pada faktor non-keuangan.

\section{SIMPULAN}

Berdasarkan hasil pengujian hipotesis dalam penelitian ini menunjukkan bahwa penekanan orientasi keuangan dan non-keuangan dalam penganggaran modal, tidak ada bukti signifikan pengambil keputusan memberikan penekanan yang lebih tinggi pada arus kas masuk (orientasi keuangan) daripada orientasi non-keuangan.Dampak insentif pribadi untuk proyek dapat dilanjutkan, terdapat bukti signifikan pengambil keputusan memberikan penekanan yang lebih tinggi pada arus kas masuk dan penekanan yang lebih rendah pada arus kas keluar namun tidak ada bukti signifikan pengambil keputusan memberikan penekanan yang lebih tinggi pada orientasi non keuangan daripada orientasikeuangan dalam penganggaran modal. Sedangkan dampak insentif pribadi dan pemantauan untuk proyek dapat dilanjutkan, terdapat bukti signifikan pengambil keputusan memberikan penekanan yang lebih rendah pada arus kas masuk dan penekanan yang lebih tinggi pada arus kas keluar namun tidak ada bukti signifikan 
pengambil keputusan memberikan penekanan yang lebih tinggi pada orientasi non keuangan daripada orientasi keuangan.Berdasarkan hasil penelitian ini terdapat beberapa implikasi bagi perusahaan dan pengambil keputusan penganggaran modal, penelitian ini diharapkan mampu menjadi sarana informasi bagi perusahaan sehingga perusahaan lebih mampu mempertimbangkan adanya insentif dan pemntauan dalam proses penganggaran modal. Bagi pengambil keputusan, menjadi sarana informasi dan pertimbangan dalam proses penganggaran modal.

\section{DAFTARPUSTAKA}

Bennuona, K., Meredith, GG, \& Merchant, T. 2010. Improved Capital Budgeting Decision Making: Evidence From Canada. Management Decision. 48(2): 225-247.

Brigham Eugene E dan Houston, Joei F. 2012. Dasar-Dasar Manajemen Keuangan .Edisi 11.Alih bahasa Ali Akbar Yulianto. Jakarta: Salemba Empat.

Brown, C. E., \& Solomon, I. 1993.An Experimental Investigation Of Explanations For Outcome Effects On Appraisals Of Capital Budgeting Decisions. Contemporary Accounting Research. 10(1): 83-111.

Burns, R. M., \& Walker, J. 2009. Capital Budgeting Surveys: The Future Is Now. Journal of Applied Finance. 19(1/2): 78-90.

Butler, R., Davis, L., Pike, R., \& Sharp, J. (1993).Strategic Investment Decisions: Theory, Practice, and Process. London, England: Routledge.

Canteralli, C. C., Flyvbjerg, B., Molin, E. J. E., \& van Wee, B. 2008. Cost Overruns In LargeScale Transportation Infrastructure Projects: Explanations And Their Theoretical Embeddedness. European Journal of Transport Infrastructure Reasearch. 10(1): 5-18.

Carr, C., \& Tomkins, C. 1998.Context, Culture And The Role Of The Finance Function In Strategic Decisions: A Comparative Analysis Of Britain, Germany, The USA And Japan. Management Accounting Research. 9(1): 213-239.

Chen, S. 2008. DCF Techniques And Nonfinancial Measures In Capital Budgeting: A Contingency Approach Analysis. Behavioral Research in Accounting. 20(1): 13-29.

Cheng, M. M., \& Mahama, H. 2011.The Impact Of Capital Proposal Guidelines And Perceived Preparer Biases On Reviewers' Investment Evaluation Decisions. Australian Journal of Management. 36(3): 349-370.

Cheng, M. M., Schulz, A. K. D., Luckett, P. F., \& Booth, P. 2003. The Effects Of Hurdle Rates On The Level Of Escalation Of Commitment In Capital Budgeting. Behavioral Research in Accounting. 15(1): 63-86.

Chenhall, R. H., \& Morris, D. 1993. The Role Of Post Completion Audits, Managerial Learning, Environmental Uncertainty And Performance. Behavioral Research in Accounting. 5(1): 170-186.

Davis, J.H., Schoorman, F.D. and Donaldson, L. 1997.Toward A Stewardship Theory Of Management. Academy of Management Review. 22 (1): 20-47.

Dayananda, D., Irons, R., Harrison, S., Herbohn, J. and Rowland, P. 2002. Capital Budgeting: Financial Appraisal of Investment Projects. Edinburg: Cambridge University Press.

Efrilna, Putri. 2018. Pengaruh Skema Pemberian Insentif dan Tanggung Jawab Personal Terhadap Budgetary Slack. Jurnal Riset Akuntansi. Universitas Negeri Padang.

English, T. 2001. Tension Analysis In International Organizations: A Tool For Breaking Down Communication Barriers. The International Journal of Organizational Analysis. 9(1): 58-83.

Frezatti, F., de Souza Bido, D., Da Cruz, A. P. C., Barroso, M. F. G., \& de Camargo Machado, M. J. 2013..Investment Decisions On Long-Term Assets: Integrating Strategic And Financial Perspectives. European Accounting Review. 22(2): 297-336. 
Savika Wulandaridan Grace Tianna Solovida :Pengaruh Insentif Dan Pemantauan : Dampak Terhadap Orientasi Keuangan Dan Non-Keuangan Dalam Penganggaran Modal

Ghozali, Imam. 2018. Aplikasi Analisis Multivariate Dengan Program IBM SPSS 25.Fakultas Ekonomika dan Bisnis. Semarang: Universitas Diponegoro Semarang

Guilding, C. 2003. Hotel Owner/Operator Structures: Implications For Capital Budgeting Process. Management Accounting Research.14(3): 179-199.

Gordon, L. A., \& Pinches, G. 1984. Improving Capital Budgeting: A Decision Support System Approach. Reading, Mass.: Addison-Wesley.

Haka, S. F. 2007.A Review of the Literature on Capital Budgeting and Investment Appraisal: Past, Present, and Future Musings. In C. Chapman, A. G. Hopwood \& M. D. Shields (Eds.), Handbook of Management Accounting Research . 2: 697728. New York, NY: Elsevier.

Handoko, T.Hani. 2000. Manajemen Personalia dan Sumberdaya Manusia. Yogyakarta:Penerbit BPFE.

Hensher, D. A., Rose, J. M., \& Greene, W. H. 2005. Applied Choice Analysis: A Primer. Cambridge, England: Cambridge University Press.

Hiebl, MRW. 2015.Agency and Stewardship Attitudes of Chief Financial Officers in Private Companies. 7 (1): 4-23.

Hosmer, D.W., and Lemeshow, S. 1989. Applied Logistic Regression. John Willey, New York.

ISHC.2015. CapEx2014.A Study of Capital Expenditures in the Hotel Industry (pp. 1243). Lansing, MI: American Hotel \& Lodging Educational Institute.

Jensen, M., \& Meckling, W. 1976.Theory of The Firm: Managerial Behavior Agency Cost, and Ownership Structure. Journal of Finance Economics. 3: 305 - 360.

Kariuki. 2010. Budgeting: A Fundamental Management Tool. Volume 1. Kasneb Newsline.

Kadous, K., Koonce, L., \& Towry, K. L. 2005.Qualification and persuasion in managerial judgement.Contemporary Accounting Research. 22(3): 643-686.

Kengatharan, M. N. L. 2015. Capital budgeting practices: evidence from Sri Lanka. Journal of Advances in Management Research. 12 (1): 55 - 82.

Kerler III, W. A., Fleming, A. S., \& Allport, C. D. 2014. How Framed Information and Justification Impact Capital Budgeting Decisions. In M. J. Epstein \& J. Y. Lee (Eds.), Advances in Management Accounting (Vol. 23, pp. 181-210). Emerald Group Publishing Limited.

Khalil \& O 'Sullivan. 2017.Meditari Accounting Research: Incentives and monitoring: impact on the financial and non-financial orientation of capital budgeting. Emerald Group Publishing Limited.

Koch, B., Mayper, A. G., \& Wilner, N. 2009.The interaction of accountability and postcompletion audits on capital budgeting decisions. Academy of Accounting and Financial Studies Journal. 13: 1-27.

Lima, A. C. Silveira, J. A. G. Matos, F. R. N. \& Xavier, A. M. 2017. A qualitative analysis of capital budgeting in cotton ginning plants.Qualitative Research in Accounting \& Management.

Lubis, A. I. 2013. Akuntansi Keperilakuan: Akuntansi Multiparadigma. Edisi ketiga. Jakarta. Salemba Empat.

Luce, M. F. 1998. Choosing to avoid: coping with negatively emotion-laden consumer decisions. Journal of Consumer Research. 24(4): 409-433.

Merchant, Kanneth A. \&Van der Stade, Wim A. 2014. Management control systems. Edisi ketiga. Jakarta: Salemba Empat.

Mukherjee, T. K. 1987. Capital-budgeting surveys: The past and the future. Review of Business and Economic Research, 22(2), 37-56. 
Netter, J., Kutner, M.H., Nachtseim, C.J and Wasserman, W. 1996).AppliedLinear Statistical Models.Fourth edition. The McGraw-Hill Companies,Inc., United States of America.

Otley, David T. 1980. The Contigency Theory of Management Accounting: Achievement and Prognosis. Accounting Organization and Society.5: 413-428.

Porwal, L. S., \& Singhvi, S. S. (1978).A comparative study of capital expenditure evaluation techniques. Long Range Planning, 11(5), 25-31.

Quirin, G.D. (1967), The capital expenditure decision.

Riyanto, Bambang. 2015. Dasar-Dasar Pembelanjaan Perusahaan. Edisi Keempat. Yogyakarta: BPFE.

Segelod, E. 1998.Capital budgeting in a fast-changing world, Long Range Planning. 31 (4): 529-541.

Suadana, I Made. (2011). Manajemen Keuangan Perusahaan Teori \& Praktek. Jakarta: Erlangga.

Swain, M. R., \& Haka, S. F. 2000 .Effects of information load on capital budgeting decisions. Behavioral Research in Accounting, 12, 171.

Triastuti, Ningsih, \& Diba..2018. Analisis Capital Budgeting Dalam Meningkatkan Keputusan Investasi Pada PT. Samudera Indonesia. Jurnal Riset Akuntansi Paradigma. 5(1).

Utomo, Setyo. 2009.Model Regresi Logistik Untuk Menunjukkan Pengaruh Pendapatan Per Kapita, Tingkat Pendidikan, Dan Status Pekerjaan Terhadap Status Gizi Masyarakat Kota Surakarta.

Van Horne, J.C, \& Wachiwicz.2008. Fundamental of Financial Management.Salemba. Jakarta.

Wagner III, J. A., \& Gooding, R. Z. 1997. Equivocal information and attribution: an investigation of patterns of managerial sensemaking. Strategic Management Journal, 18(4), 275-286.

Waldron, M., \& Fisher, R. 2017. Values and ethical judgments: the adequacy of students as surrogates for professional accountants. Meditari Accountancy Research, 25(1), 3764.

Zeelenberg, M., Inman, J. J., \& Pieters, R. 2001.What We Do When Decisions Go Awry: Behavioral Consequences of Experienced Regret. In E. U. Weber, J. Baron \& G. Loomes (Eds.), Conflict and Tradeoffs in Decision Making (pp. 136-155). Cambridge, UK: Cambridge University Pres 